\title{
ALTERATION OF PODZOLIZED TILLS BY ACID LOAD NEAR Ni-Cu SMELTERS AT MONCHEGORSK, KOLA PENINSULA, RUSSIA
}

\author{
MARJA LIISA RÄISÄNEN, EELIS PULKKINEN \\ and MATTI KONTIO
}

RÄISÄNEN, MARJA LIISA; PULKKINEN, EELIS and KONTIO, MATTI, 1994: Alteration of podzolized tills by acid load near $\mathrm{Ni}-\mathrm{Cu}$ smelters at Monchegorsk, Kola Peninsula, Russia. Bull. Geol. Soc. Finland 66, Part I, 1938.

Mineralogy and geochemistry of podzolized tills was studied in the area of dieback forest near the Ni-Cu smelters at Monchegorsk, and less extensively forest damage near by Apatity and Kirovsk in the Russian Kola Peninsula. The abundances of main elements $(\mathrm{Si}, \mathrm{Al}, \mathrm{Fe}, \mathrm{Mg}, \mathrm{Ca}, \mathrm{K}, \mathrm{Na}$ ) in the $<64 \mu \mathrm{m}$ fraction were determined by the hot aqua regia digestion method and inductively coupled plasma spectrometry. The clay mineralogy of the silt plus clay fraction was examined by X-ray diffraction after selective extraction and heating treatments.

At all study sites, trioctahedral mica and chlorite were totally weathered from the silt and clay fraction $(<64 \mu \mathrm{m})$ of the eluvial layer, leaving behind interstratified mica-vermiculite-smectite clays. In general, the mixed-layer clay of the eluvial layer had low levels of hydroxy interlayering. Illuviated layers were characterized by hydroxy interlayered vermiculite-chlorite. The abundance of chlorite and mica was greater, and the degree of interlayering lower, in parent tills than in the overlying illuviated layers. Regardless of differences in bedrock and till geochemistry, the weathering sequence throughout the podzolized till profile was coherent at most of the sampling sites.

Exceptionally, in a few profiles sampled at the totally destroyed forest site, the swelling mixed-layer clay of the eluvial layer displayed a neochloritized structure. On the basis of XRD patterns and geochemistry of the samples, it was inferred that a short-term decomposition of plagioclase had promoted, via inputs of Al-hydroxides, the transformation of mica-vermiculite-smectite to a poorly crystalline interstratification of chlorite-aluminous montmorillonite. The accelerated weathering occurring occasionally in exposed places was probably activated by the strongly acidic load in the vicinity of the smelters and the city of Monchegorsk.

Key words: environmental geology, soils, Podsols, till, geochemistry, clay minerals, mica group, weathering, pollution, acidification, Monchegorsk, Kola Peninsula, Russian Federation.

Marja Liisa Räisänen: Geological Survey of Finland, Geochemistry Department, P.O. Box 1237, 70211 Kuopio, Finland.

Eelis Pulkkinen, Matti Kontio: Geological Survey of Finland, P.O. Box 77, 96101 Rovaniemi, Finland 


\section{INTRODUCTION}

Till in the glaciated areas of Fennoscandia is a mixture of preglacial sediments and 'fresh', unweathered rock fragments derived from crystalline bedrock. In many areas, regional differences in till geochemistry can be explained by variation in the chemical composition and structure of the underlying bedrock (Koljonen 1992). The composition of till reflects processes of erosion, transport and deposition. The fine material of till tends to be enriched in phyllosilicates in the first case, and in quartz, feldspars and amphiboles in the second (Linden 1975, Perttunen 1977). However, the major part of the mineral species in the fine $(<0.06 \mathrm{~m})$ fraction of the till, especially that of sandy till, consists of quartz and feldspars (see e.g., Perttunen 1977, Melkerud 1984, Mäkinen 1992, Räisänen et al. 1992).

The quality and quantity of the chemical alteration taking place during soil processes depend largely on their duration and geochemistry of sediments. The Weichselian Ice Sheet retreated from the Kola Peninsula approximately 10,000 years ago (Ignatius et al. 1980, Niemelä et al. 1993). It is assumed, however, that pedogenesis has altered the mineral composition of tills only slightly in the northern coniferous areas (Olsson 1992, Hyyppä et al. 1992). Räisänen et al. (1989) and Olsson (1992) have calculated that weathering rates for the major minerals of podzolized tills are extremely low.

Within the last fifty years, rainwater has increasingly been acidified by sulphuric and nitric acids emitted from local and also remote anthropogenic sources in the northernmost areas of Europe (Tuovinen et al. 1990, Honkanen 1992). Acidification of rainwater has been especially intensive in the vicinity of the Ni-Cu smelters in the Russian Kola Peninsula (Kryuskov 1991). In arctic regions, the incomplete decomposition of organic material and the short period of biological activity create natural soil acidification, limiting the capacity of soils to resist anthropogenic impacts (Kasulina
1991). Moreover, as Kasulina (1991), Kontio et al. (1992) and Olsson (1992) have shown, the ion exchange capacity of till, and consequently, also the buffer capacity of the soil are low in northern forest areas.

The mobilization of $\mathrm{Al}$ from acid podzolic soils to surface and groundwaters is causing increasing concern within the general context of acid deposition from the atmosphere. An understanding of the conditions under which $\mathrm{Al}$ is released to waters requires the characterization of possible sources of mobile $\mathrm{Al}$ in the soil. The present study was aimed at examining secondary clay minerals and the stability of Al-hydroxy interlayering in that respect.

This study deals with geochemistry and mineralogy of podzolized till profiles in the vicinity of the Monchegorsk Ni-Cu smelter complex and near by Apatity and Kirovsk (Fig. 1). Of special interest was a comparison of the podzol profiles of totally destroyed forest areas with those of less damaged areas. The underlying assumption of the study was that the clay minerals characteristical for podzol soil are formed regardless of the regional differences in geochemistry. The volume and rate of weathering and acidification were assumed to depend mostly on the biogeochemical factors and climate, including the quality of rain water.

\section{General geology of the central Kola Peninsula}

Fig. 1 shows the location of the study sites in the Kola Peninsula. A large fractionated layered mafic igneous complex embedded in Archaean granitoid is the characteristic bedrock unit in the area around Monchegorsk and at site No. 1 (Gorbunov et al. 1985). Volcanics, mainly mafic tuffs and lavas, surrounded by granite gneiss, predominate at the area of site No. 2 (Belyaev et al. 1976). The till at site No. 3 lies on granite gneiss bedrock. At site No. 4, located southeast of Kirovsk, the bedrock consists of granite gneiss and mafic rocks, varying in composition from mafic to ultramafic (Belyaev et al. 1976). 


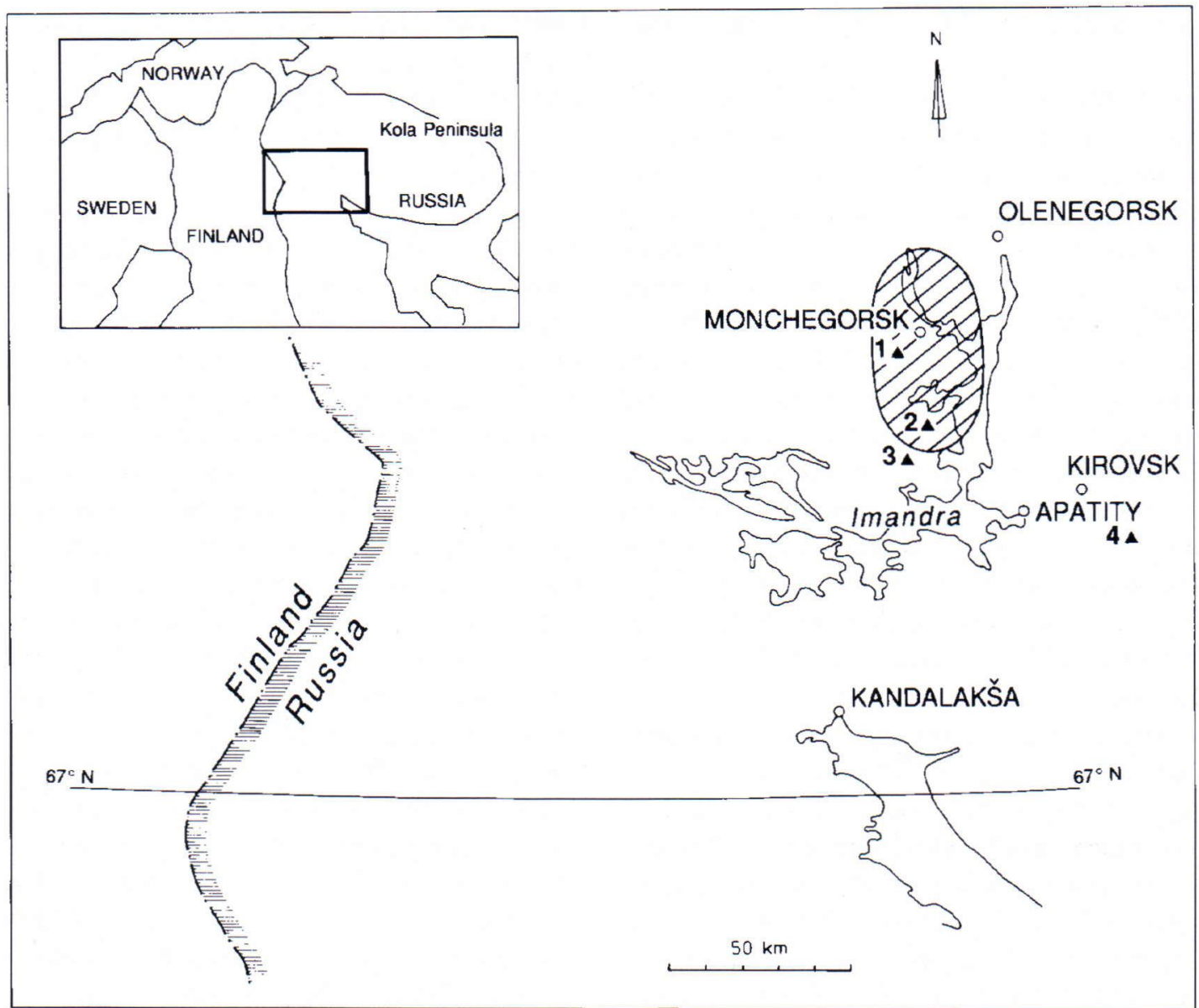

Fig. 1. Sampling sites in the Kola Peninsula, Russia. The hatched area shows the area in the vicinity of the $\mathrm{Ni}-\mathrm{Cu}$ smelters at Monchegorsk where the forest is totally destroyed.

\section{Air pollution and forest damage \\ in the central Kola Peninsula}

According to Kryuskov (1991), the S deposition within $4 \mathrm{~km}$ of the $\mathrm{Ni}-\mathrm{Cu}$ smelters at Monchegorsk in 1989 was an estimated $20-25 \mathrm{~g} \mathrm{~m}^{-2}$, while $7 \mathrm{~km}$ away from the smelter complex it was $3-5 \mathrm{~g} \mathrm{~m}^{-2}$. In the same year, the deposition of $\mathrm{Ni}, \mathrm{Cu}, \mathrm{Mn}$ and $\mathrm{Zn}$ was estimated at $6 \mathrm{~g}$ per $\mathrm{m}^{2}$ total in the area close to the smelters and $2 \mathrm{~g}$ per $\mathrm{m}^{2}$ at $7 \mathrm{~km}$ distance.

In 1989 the area of totally destroyed forest around Monchegorsk was approximately $300 \mathrm{~km}^{2}$ and that of the partially destroyed forest $1000 \mathrm{~km}^{2}$ (Kryuskov \& Makarova 1989, as reported in Honkanen 1992). At site No. 1, all spruce trees and most of the birch bushes were dead, and in many places also ground vegetation was destroyed. Wide areas were barren and lacking a humus layer. Only in a few places with decomposed old stumps and stems was a humus layer $(2-4 \mathrm{~cm})$ observed.

At site No. 2, where the forest was partially destroyed, spruce trees were afflicted by intense needle loss, and trees were dead in limited areas. In places ground vegetation was dead, too, and the 
mineral soil barren. Blueberry (Myrtillus), a typical dwarf shrub in Kola spruce forests, was alive only at site No. 2 and at the background sites Nos. 3 and 4 (Jevtjugina 1991). Site No. 1 had supported blueberry before the deterioration (Kasulina, pers. comm.).

In the background area, over $20 \mathrm{~km}$ away from the emission source, where the forest was considerably less damaged, the estimated S deposition in 1989 was $1-2 \mathrm{~g} \mathrm{~m}^{-2}$ and the metal deposition 0.05-0.5 $\mathrm{g} \mathrm{m}^{-2}$ (Kryuskov 1991). At site No. 3, located $30 \mathrm{~km}$ from the Ni-Cu smelters of Monchegorsk, spruce trees suffered serious defoliation and dead trees were sporadically observed. The ground vegetation was alive, and significant erosion of humus was not observed. Site No. 4, which is about $20 \mathrm{~km}$ southeast of the city of Kirovsk and $80 \mathrm{~km}$ from the Ni-Cu smelters of Monchegorsk, is considered as an unpolluted spruce forest area (Jevtjugina 1991).

\section{MATERIALS AND METHODS}

\section{Soil sampling}

Glacial sediments at study sites consist of a stony sandy till (Niemelä et al. 1993). According to Kasulina (1991), the soil is an Fe-Al humus podzol. The majority of the gravel and boulders of the till had originated from the local bedrock. We therefore assume that at most of the sampling locations the bedrock had had a dominant influence on the chemical composition and primary mineralogy of the sandy till. This interpretation is based on field observations made during the sampling.

Eluvial (E) and illuviated (B, BC) mineral soil layers characteristical for podzol soil were sampled at all study sites. Two profile types were sampled at site No. 1: a profile with a grey-coloured E layer, and a profile without a distinct E layer. The distance between these profile types varied from one to few meters independently of the topographical changes.
A similar variation in the appearance of the top soil layer was not observed in profiles of sites 2-4. At these sites the E layer varied from light grey to brownish grey in colour.

At all study sites, the illuviated layers graded from dark brown or reddish brown (B) to yellowish brown (BC) in colour. If the thickness of the illuvial (B) layer was over $5 \mathrm{~cm}$, two illuvial $\left(\mathrm{B}_{\mathrm{h}}, \mathrm{B}_{\mathrm{s}}\right)$ layers were sampled separately. The subindexes $B_{h}$ and $B_{s}$ refer to the predominant accumulation of organic matter and inorganic sesquioxides, respectively. In addition, the greenish grey layer of the parent sandy till (C) was sampled at all study sites. The depth of the $\mathrm{C}$ layer varied from $30 \mathrm{~cm}$ to $80 \mathrm{~cm}$ depending on the abundance of boulders and the thickness of podzolized layers.

At site No. 1, altogether six profiles were sampled in barren areas and areas with dead and green ground vegetation of moss, grass and crowberry (Empetrum). At site No. 2, one profile was sampled in a barren area and another profile in an area with green ground vegetation of moss, crowberry and blueberry. Three profiles were sampled at site No. 3 and one profile at site No. 4. Samples were taken in summer 1989, and at site No. 1 anew in 1991.

\section{Chemical analysis}

The clay minerals in the $<2 \mu \mathrm{m}$ fraction of sandy tills have a major influence on soil reactions. However, since the clay-size fraction commonly comprises less than $10 \%$ of podzolized sandy till, we preferred a mixture of silt and clay fractions $(<64 \mu \mathrm{m})$ for the X-ray diffraction and geochemical analysis. The same fraction was used in an earlier study (Räisänen et al. 1992). Other reasons for choosing the coarser fraction were the following: 1) Clay minerals in the silt fraction are suggested to be a source of readily mobilizeable $\mathrm{Al}$ (Farmer et al. 1988), and 2) Characteristics of existing hydroxy-interlayers are likely to serve as an indicator of progressing acidification (Lou \& Huang 1988, Bain et al. 1990). 
Major elements ( $\mathrm{Si}, \mathrm{Al}, \mathrm{Fe}, \mathrm{Mg}, \mathrm{Ca}, \mathrm{K}, \mathrm{Na}$ ) were determined in air-dried samples sieved to $<64 \mu \mathrm{m}$ and leached with hot $\left(90^{\circ} \mathrm{C}\right)$ aqua regia. Altogether 56 samples were analysed with an inductively coupled plasma spectrometer (Thermo Jarrel Ash Polyscan61E ICP-AES).

According to Räisänen et al. (1992), the hot aqua regia selectively dissolves trioctahedral micas (mainly biotite), clay minerals and amorphous precipitates of tills. The authors suggest that the hot aqua regia does not destroy crystals of quartz, feldspars and amphiboles, though it may leach elements in minor amounts from broken surfaces of these minerals. Accordingly, we here assume that the elements extractable with hot aqua regia mostly reflect the composition of trioctahedral micas, clay minerals and precipitates. Since silica partially reprecipitated during the digestion, results of the silica assay were not used in the present study.

\section{Mineralogical study}

Micas and clay minerals were studied by X-ray diffraction (XRD) in 30 samples from seven podzol profiles. Four profiles were in the destroyed forest area (sites Nos. 1 and 2) and three in the background area.

Extractants for the XRD analyses were $1 \mathrm{M} \mathrm{KCl}$, $0.025 \mathrm{MNH}_{4} \mathrm{NO}_{3}$ acidified to $\mathrm{pH} 2.3-2.4\left(\mathrm{AS}_{\mathrm{pH} 2.3-2.4}\right)$ and $\mathrm{NH}_{4}$ oxalate buffered at pH3.0 (Räisänen 1989 , Räisänen et al. 1992). The whole set of treatments of subsamples was as follows: 1) air-dried and in some cases also heated at $200^{\circ} \mathrm{C}$ and $550^{\circ} \mathrm{C}, 2$ ) $\mathrm{AS}_{\mathrm{pH} 2.3-2.4}$ extracted, 3) $\mathrm{AS}_{\mathrm{pH} 2.3-2.4}$ extracted and heated at $200^{\circ} \mathrm{C}$ and $\left.550^{\circ} \mathrm{C}, 5\right) \mathrm{K}$ saturated, 6) $\mathrm{K}$ saturated and heated at $200^{\circ} \mathrm{C}$ and $\left.550^{\circ} \mathrm{C}, 7\right) \mathrm{NH}_{4}$ oxalate extracted at $\mathrm{pH} 3.0$, and 8) $\mathrm{NH}_{4}$ oxalate extracted at $\mathrm{pH} 3.0$ and heated at $200^{\circ} \mathrm{C}$ and $550^{\circ} \mathrm{C}$. The expanding property of clay minerals was studied upon ethylene glycol solvation, after the acid $\mathrm{NH}_{4}$ oxalate extraction.

The acidified $\mathrm{NH}_{4} \mathrm{NO}_{3}$ treatment is a modification of the acid neutralizing capacity (ANC) method, and, according to Räisänen et al. (1992), the XRD pattern after the $\mathrm{AS}_{\mathrm{pH} 23-2.4}$ extraction is similar to that after the $\mathrm{K}$ saturation and, therefore, shows characteristics of the interlayering. Generally, the ANC method is used to measure the solubility of aluminium and base cations in buffering reactions of soils poor in carbonates (Räisänen 1989). The extractant used in the XRD analysis contained a dilute ammonium nitrate solution acidified with 0.1 $\mathrm{N} \mathrm{H}_{2} \mathrm{SO}_{4}$ to $\mathrm{pH}$ 2.3-2.4 (Räisänen et al. 1992).

The ammonium oxalate $\mathrm{pH} 3.0$ extraction, modified after the method of McKeague \& Day (1966), was used to leach Al and Fe hydroxides from surface coatings and interlayers of clay minerals (Räisänen et al. 1992). The acid $\mathrm{NH}_{4}$ oxalate more effectively dissolves iron precipitates, and Al-hydroxides bound to interlayer sites, than the $\mathrm{AS}_{\mathrm{pH} 2.3-2.4}$ extractant (Räisänen et al. 1992). Moreover, the oxalate solution leaches more reactive Al-rich species from interlayers, compared to the resistant interlayer materials extracted by hot citrate solutions (Farmer et al. 1988).

The fractions studied were $<60 \mu \mathrm{m}$ and $<40 \mu \mathrm{m}$ depending on the abundance of silt and clay in the samples. The $<10 \mu \mathrm{m}$ fraction of the samples rich in silt was prepared for comparison. Oriented aggregates for XRD analysis were prepared with the pipette sampling technique. The precision and repetition of the XRD patterns were examined in duplicate treatments of subsamples. Slides were run at a scanning rate of $1^{\circ}$ per minute in the Philips diffractometer with $\mathrm{Ni}$ filtered $\mathrm{Cu} \mu$-radiation. The XRD analysis handbooks edited by Thorez (1975) and Dixon \& Weed (1977 and 1989) were used for mineral identification.

\section{RESULTS AND DISCUSSION}

\section{Chemical variation of the podzolized till profiles}

The fine fraction of the parent till in the area of the totally destroyed forest ( 
Table 1. Mean, maximum and minimum values (weight-\%) of $\mathrm{Al}_{2} \mathrm{O}, \mathrm{Fe}, \mathrm{O}, \mathrm{MgO}, \mathrm{K}, \mathrm{O}, \mathrm{CaO}, \mathrm{Na}$, $\mathrm{O}$ extractable in aqua regia from $<64 \mu \mathrm{m}$ fraction of podzolized till layers at the study sites, the central Kola Peninsula, Russia. Abbreviations for the layers are $E=$ eluvial (grey), $B=$ upper illuvial (dark brown), $B C=$ lower illuviated (yellowish brown), $C$ = parent till (greenish grey).

Area of totally destroyed forest 6 proliles, sitc No. 1
Arca of partially destroyed forest

2 proliles, sitc No. 2
Background area

4 profiles, sites Nos. 3 and 4

\begin{tabular}{|c|c|c|c|c|c|c|c|c|c|c|c|c|}
\hline $\mathrm{Al}_{2} \mathrm{O}_{3}$ & $E$ & B & $\mathrm{BC}$ & $\mathrm{C}$ & $E$ & B & $\mathrm{BC}$ & $\mathrm{C}$ & $E$ & B & $\mathrm{BC}$ & C \\
\hline Mean & 0.81 & 7.62 & 7.48 & 4.84 & 0.29 & 4.40 & 3.25 & 2.27 & 0.16 & 4.66 & 2.58 & $\left.2.48^{\circ}\right)$ \\
\hline Min. & 0.60 & 2.74 & 4.99 & 3.66 & 0.27 & 2.59 & 3.11 & 2.22 & 0.15 & 1.71 & 1.45 & 1.13 \\
\hline Max. & 1.21 & $\begin{array}{c}12.5 \\
1\end{array}$ & 9.48 & 5.79 & 0.30 & 7.52 & 3.39 & 2.32 & 0.20 & 7.01 & 4.64 & 3.83 \\
\hline $\mathrm{Fe}_{2} \mathrm{O}_{3}$ & $E$ & B & $\mathrm{BC}$ & $\mathrm{C}$ & $\mathrm{E}$ & B & $\mathrm{BC}$ & $\mathrm{C}$ & $E$ & B & $\mathrm{BC}$ & $\mathrm{C}$ \\
\hline Mean & 1.02 & 4.08 & 2.96 & 2.39 & 0.87 & 5.59 & 2.72 & 2.12 & 0.21 & 3.88 & 1.39 & $\left.1.74^{\circ}\right)$ \\
\hline Min. & 0.52 & 2.86 & 2.15 & 2.29 & 0.64 & 3.77 & 2.70 & 1.83 & 0.11 & 1.13 & 1.01 & 1.05 \\
\hline Max. & 1.71 & 6.89 & 3.81 & 2.62 & 1.10 & 7.65 & 2.73 & 2.41 & 0.39 & 5.79 & 2.26 & 2.12 \\
\hline $\mathrm{MgO}$ & $E$ & $B$ & $\mathrm{BC}$ & $\mathrm{C}$ & $\mathrm{E}$ & B & $\mathrm{BC}$ & $\mathrm{C}$ & $E$ & B & $\mathrm{BC}$ & C \\
\hline Mcan & 0.14 & 0.50 & 0.82 & 1.00 & 0.07 & 0.48 & 0.68 & 0.58 & 0.03 & 0.4 .5 & 0.47 & $\left(1.68^{\circ}\right)$ \\
\hline Min. & 0.07 & 0.19 & 0.34 & 0.87 & 0.06 & 0.31 & 0.60 & 0.50 & 0.12 & 0.26 & 0.37 & 0.42 \\
\hline Max. & 0.34 & 1.04 & 1.10 & 1.14 & 0.07 & 0.67 & 0.76 & 0.65 & 0.05 & 0.69 & 0.81 & 0.93 \\
\hline $\mathrm{K}_{2} \mathrm{O}$ & $E$ & B & $\mathrm{BC}$ & $\mathrm{C}$ & $E$ & B & $\mathrm{BC}$ & C & $E$ & B & $\mathrm{BC}$ & $\mathrm{C}$ \\
\hline Mcan & 0.02 & 0.05 & 0.07 & 0.13 & 0.02 & 0.09 & 0.25 & 0.25 & 0.04 & 0.09 & 0.10 & $\left(0.18^{\circ}\right)$ \\
\hline Min. & 0.01 & 0.03 & 0.03 & 0.08 & 0.02 & 0.06 & 0.23 & 0.21 & 0.03 & 0.05 & 0.07 & 0.13 \\
\hline Max. & 0.03 & 0.09 & 0.13 & 0.18 & 0.02 & 0.12 & 0.27 & 0.28 & 0.05 & 0.13 & 0.16 & 0.22 \\
\hline $\mathrm{CaO}$ & $E$ & B & $\mathrm{BC}$ & C & $E$ & B & $\mathrm{BC}$ & C & $E$ & B & $B C$ & C. \\
\hline Mcan & 0.15 & 0.31 & 0.50 & 0.62 & 0.11 & 0.25 & 0.32 & 0.36 & 0.06 & 0.18 & 0.28 & $\left(0.42^{\circ}\right.$ \\
\hline Min. & 0.13 & 0.21 & 0.36 & 0.54 & 0.09 & 0.17 & 0.30 & 0.33 & 0.05 & 0.11 & 0.21 & 0.40 \\
\hline Max. & 0.19 & 0.46 & 0.66 & 0.67 & 0.13 & 0.37 & 0.35 & 0.39 & 0.06 & 0.30 & 0.43 & 0.43 \\
\hline $\mathrm{Na}_{2} \mathrm{O}$ & $E$ & B & $\mathrm{BC}$ & C & $E$ & B & $\mathrm{BC}$ & $\mathrm{C}$ & $\mathrm{E}$ & B & $\mathrm{BC}$ & $C^{\prime}$ \\
\hline Mean & 0.05 & 0.09 & 0.11 & 0.13 & 0.08 & 0.10 & 0.09 & 0.09 & 0.05 & 0.05 & 0.0 .5 & $\left(0.077^{*}\right)$ \\
\hline Min. & 0.01 & 0.04 & 0.07 & 0.08 & 0.08 & 0.08 & $0 .(19)$ & 0.09 & 0.114 & 0.04 & 0.05 & 0.07 \\
\hline Max. & 0.09 & 0.14 & 0.17 & 0.17 & 0.08 & 0.11 & 0.09 & 0.09 & 0.05 & 0.06 & 0.07 & 0.08 \\
\hline
\end{tabular}

-) Mean value of two samples 
$\mathrm{Al}, \mathrm{Fe}, \mathrm{Mg}$ and $\mathrm{Ca}$ extractable in aqua regia than till in the area of partial forest destruction (site No. 2) (Table 1). The fine fraction of the parent till in the background area with less forest damage (sites Nos. 3-4) contained almost equal amounts of the aqua regia leachable elements to that at site No. 2 (Table 1). Field observations indicated that bedrock, and also rock fragments of the till, at site No. 1 were dominantly mafic, amphibole-rich and anorthosite gabbros. At the other study sites (sites Nos 2-4) the parent material of the till consisted of felsic and mafic rocks in variable abundance. Differences in abundances of the major elements at the various sites are therefore suggested to be due to the bedrock variation.

At all the study sites the $<64 \mu \mathrm{m}$ fraction of the eluvial layer was characterized by an extremely low concentration of $\mathrm{K}$ (Table 1 ), which indicates the absence of trioctahedral micas (Räisänen et al. 1992). Compared with the parent till, concentrations of $\mathrm{K}$ were also decreased in the upper illuvial (B) layer (Table 1). On the basis of the chemical variation within the profiles, it is suggested that the decreased contents of $\mathrm{K}, \mathrm{Mg}$ and $\mathrm{Ca}$ in the eluvial layer and the enrichment of $\mathrm{Al}$ and $\mathrm{Fe}$ in the underlying layers (B, $\mathrm{BC}$ ) of all profiles are linked to the partial decomposition of ferromagnesian minerals in the eluvial layer, and in some profiles also in the illuvial (B) layers (Table 1).

The decrease in Na concentrations of the eluvial layer was analogous to that of $\mathrm{Ca}$ only within profiles of the totally destroyed forest area (site No. 1, Table 1). At other sites concentrations of Na were more or less constant through the profile. Räisänen et al. (1992) inferred that the constant and low content of $\mathrm{Na}$ in tills was indicative of the presence of unweathered plagioclase. The increased leaching of $\mathrm{Na}$ and $\mathrm{Ca}$ downwards in the podzol profiles in the totally destroyed area is probably due to a partial weathering of plagioclase. Further support for this is the marked increase of $\mathrm{Al}$ in the underlying $\mathrm{B}$ and BC layers at site No. 1 (Table 1).

\section{Distribution of micas within the podzolized till} profiles

The distribution of micas within the profiles was broadly alike at all sites. Two major groups, dioctahedral and trioctahedral forms, occurred in podzolized tills in both the destroyed forest area and the background area with less damaged forest. As seen in Fig. 2, the ratio of the intensities of the peaks at $5 \AA$ and $10 \AA$ decreased downwards in the podzol profile, suggesting that dioctahedral mica predominated in the eluvial layer and the trioctahedral mica in the lower podzol layers and parent till (see Soveri \& Hyyppä 1966, Barnhisel 1977). The trioctahedral mica was totally absent in the eluvial layer. Occasionally both mica forms were observed, or both were absent in the brown illuvial $\left(\mathrm{B}_{\mathrm{h}}, \mathrm{B}_{\mathrm{s}}\right)$ layers.

In most of the samples, di- and trioctahedral micas gave a broad basal reflection at $10 \AA$, indicating a partial weathering of the sheet structure (e.g. Figs 2 and 3). However, in no sample could the expanding properties of weathered mica layers be reliably interpreted upon ethylene glycol solvation. In the samples of the eluvial layer the intensity of the $10 \AA$ peak was decreased upon ethylene glycol solvation, and several humps appeared between 10 and $12 \AA$ (Figs 2 and $3 \mathrm{~d}$ ). The same kind of decrease was observed in some samples of the illuviated (B, BC) layers. In the samples of the parent till, by contrast, the $10 \AA$ peak remained unaltered upon ethylene glycol solvation. The change in the peak intensity upon glycol solvation may imply a decrease in the weathering rate of the mica structure from top to bottom of the podzolized till profile.

\section{Mixed-layer clay minerals in the eluvial layer of podzolized tills}

Randomly interstratified clays dominated the clay mineral group of the eluvial layers at all the study sites. According to our interpretation of the XRD 
analysis, mica-, vermiculite- and smectite-like layers were present in variable abundance in the mixed-layer clay of the eluvial layer in most profiles in both the destroyed forest area and the background area. The characteristics of the interstratified clay mineral after several treatments are described in the

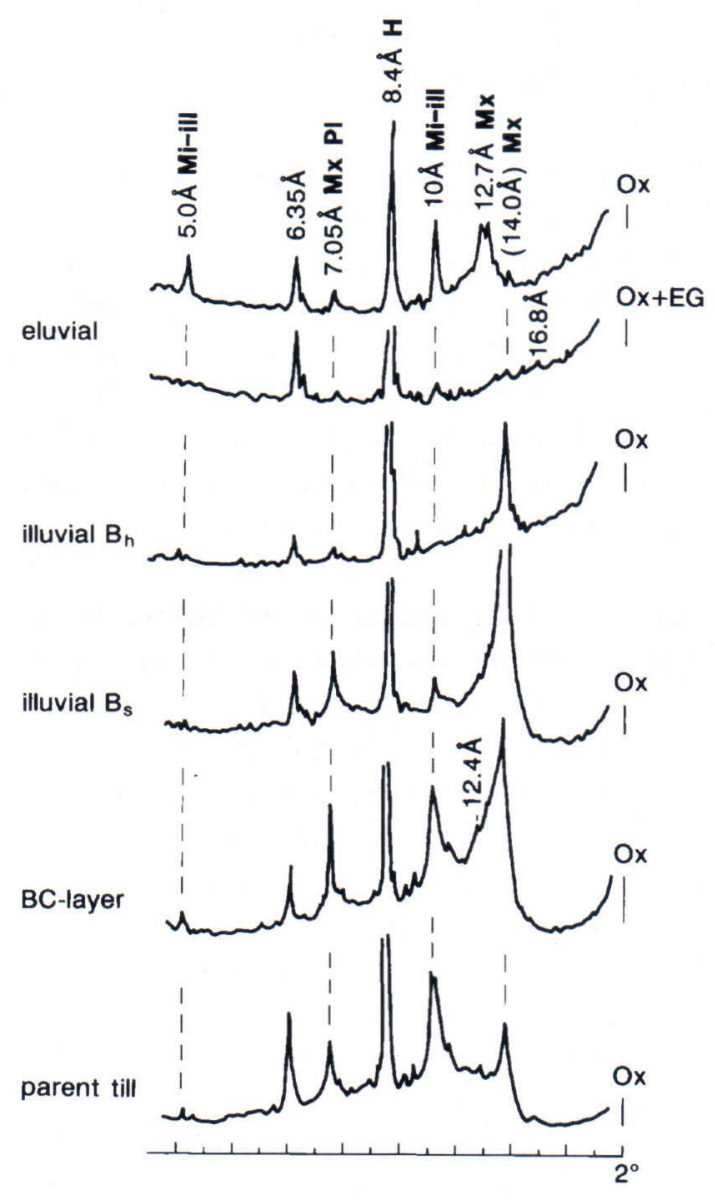

Fig. 2. XRD traces of the oxalate $(O x)$-treated samples of the podzol profile from site No. 2 (dead ground vegetation), Monchegorsk. The grain size of the subsamples was $<40 \mu m$. Key to the treatments: $O x=$ oxalate extracted, $O x+E G=$ oxalate extracted and ethylene glycol solvation. Key to the XRD traces: Mx = mixed-layer clay, Mi-ill = illitic mica (di-or trioctahedral), $H=$ hornblende, $P l=$ plagioclase, and $T=$ talc. following.

The XRD patterns of most of the air-dried, $\mathrm{K}$-saturated and oxalate-treated samples displayed the same basal reflection between $12 \AA$ and $13 \AA$ without integral diffraction peaks (Fig. 3). Upon K saturation at room temperature the basal spacing at $12-13 \AA$ partially collapsed to $10 \AA$ indicating the presence of some 'true' vermiculite (Fig. 3b) (Barnhisel \& Bertsch 1989). Moreover, the contraction of the mixed-layer clay upon heating was coherent and independent of the extractions (see Fig. 3). The partial collapse toward $10 \AA$ upon heating at low temperature suggests that the mixed-layer clay has only a low degree of hydroxy interlayering (Fig. 3) (Barnhisel 1977, Barnhisel \& Bertsch 1989).

Upon ethylene glycol solvation the basal spacing of the mixed-layer clay shifted to $17 \AA$ (Fig. 3d). This implies that the dominant component of the interstratification has a swelling property similar to smectite (MacEwan \& Wilson 1980, Wilson 1987). According to MacEwan \& Wilson (1980), non-saturated vermiculite can only reach the spacing of $16 \AA$ upon glycol solvation. The weak residual peak at $10 \AA$ for samples solvated with ethylene glycol is suggested to indicate a minor content of mica (Fig. 3d).

The interstratified clay mineral in a few eluvial samples from the destroyed forest area displayed divergent characteristics: viz. a broad peak between $13 \AA$ and $14 \AA$ only upon K-saturation, and variable traces in the ranges 11-14 $\AA$ or 11-15 $\AA$ upon other treatments (Fig. 4). Since the K-saturation treatment at room temperature resulted in weak contraction, the divergent clay form must contain less 'true' vermiculite component than the mica-vermiculitesmectite clay occurring in other samples of the eluvial layer (cf. Figs $3 b$ and $4 b$ ). As can be seen in Figs. 3 and 4, the swelling properties upon ethylene glycol solvation were nevertheless broadly similar for the two clay forms regardless of the differences in the basal reflections upon air-drying, K-saturation and after the oxalate extraction. Furthermore, the 
basal peaks of both clay types shifted to $15 \AA$ after the acidified $\mathrm{NH}_{4} \mathrm{NO}_{3}$ extraction $\left(\mathrm{AS}_{\mathrm{pH} 2.32 .4}\right)$ (Figs. $3 \mathrm{c}$ and $4 \mathrm{a})$.

In contrast to the mica-vermiculite-smectite (Fig. 3), the divergent clay form (Fig. 4) gave weak and diffuse reflections upon heating at $200{ }^{\circ} \mathrm{C}$ and 550 ${ }^{\circ} \mathrm{C}$ after all treatments, and especially after $\mathrm{AS}_{\mathrm{pH} 23-2.4}$ extraction. Oxalate treatment of the $<10 \mu \mathrm{m}$ fraction of one sample left a weak residual peak of $14 \AA$ at $550{ }^{\circ} \mathrm{C}$ (Fig. $4 \mathrm{~d}$ ), indicating the presence of some chlorite (Barnhisel 1977). The $14 \AA$ reflection was less pronounced in the samples of the $<40 \mu \mathrm{m}$ fraction (Figs. 4a-c). In general, the diffuse collapse upon heating at $550{ }^{\circ} \mathrm{C}$ indicates the presence of interlayer contaminants (MacEwan \& Wilson 1980).

The incomplete collapse to $10 \AA$ at $550{ }^{\circ} \mathrm{C}$ is generally attributed to a higher degree of $\mathrm{Al}$-hydroxy interlayering or the presence of chlorite (Barnhisel 1977, April et al. 1986, Farmer et al. 1988). MacEwan \& Wilson (1980) proposed that diffuse and broad reflection upon heating indicate an intergrade clay with properties between chlorite and montmorillonite or vermiculite (see also Jackson 1963). Olson (1988) has reported a poorly crystalline clay mineral, whose reflections collapsed only partially to $10 \AA$ and gave a weak plateau of intensity from $12 \AA$ to $14 \AA$ upon heating to $550^{\circ} \mathrm{C}$. Similarly, the present study suggests that the divergent clay form with plateau-like reflections upon heating possessed a poorly crystalline mixed-layer structure. High concentrations of $\mathrm{Al}$ and $\mathrm{Fe}$ in the sample confirm that the clay was rich in Al- and/or Fe-hydroxides. The divergent mixed-layer clay is, therefore, identified either as a chlorite-aluminous montmorillonite (Jackson 1963, Thorez 1975) or a mixed-layer clay with vermiculitic, chloritic and smectitic components (Barnhisel 1977, Kodama \& Brydon 1968).

Mixed-layer clay minerals in illuviated $(B, B C)$ layers of podzolized tills

The illuviated (B, BC) layers in both the destroyed forest area and the background area were dominated by a clay mineral with a basal spacing at $14 \AA$ (Fig. 5). On the basis of the XRD analyses, the $14 \AA$ clay was attributed to a hydroxy-interlayered vermiculite-chlorite. The absence of higher integral peaks indicates a random interstratification of vermiculite and chlorite layers (Barnhisel 1977, Barnhisel \& Bertsch 1989).

Randomly interstratified vermiculite-chlorite did not expand upon ethylene glycol solvation in any sample of illuviated (B, BC) layers (see Fig. 5d). Neither did its peak shift to a larger spacing after $\mathrm{AS}_{\mathrm{pH} 23-2.24}$ extraction, unlike mixed-layer clay forms in the eluvial layer (cf. Figs $3 \mathrm{c}$ and $5 \mathrm{c}$ ). Furthermore, the $14 \AA$ peak in the specimens of the illuviated layers did not collapse to $10 \AA$ after any extraction until heated to $550^{\circ} \mathrm{C}$ (Fig. 5). The diffractograms recorded for samples heated to $550{ }^{\circ} \mathrm{C}$ diversely displayed broad humps or shoulders on the low angle side of the $10 \AA$ reflection. The incomplete contraction at $550^{\circ} \mathrm{C}$, and the stability of the $14 \AA$ peak after the acidifying treatment $\left(\mathrm{AS}_{\mathrm{pH} 23.32 .4}\right)$, indicate a high degree of polymerization of hydroxides in interlayer spaces of vermiculite layers (Räisänen et al. 1992, see also Rich 1968 and Carstea et al. 1970). The residual $14 \AA$ peak at $550^{\circ} \mathrm{C}$ was more marked after the oxalate extraction than after the other extractions, and indicates the presence of chlorite (see Fig. 5). According to the variable intensity of the $14 \AA$ peak at $550^{\circ} \mathrm{C}$, the abundance of chlorite must have varied from sample to sample.

Diffractograms recorded for some samples of B and $\mathrm{BC}$ layers rich in $\mathrm{Al}$ and $\mathrm{Fe}$ from the totally destroyed forest area showed broad humps after air-drying, K-saturation and $\mathrm{AS}_{\mathrm{pH} 2.3-2.4}$ extraction. Only after the oxalate extraction was a very strong spacing at $14 \AA$ with a shoulder at $15 \AA$ obtained (e.g. Fig. 6). In this case the $14 \AA$ peak collapsed less completely to $10 \AA$ at $550^{\circ} \mathrm{C}$ (Figs. 6a and 6b) than that for the sample of the illuvial layer with less increased content of $\mathrm{Al}$ and $\mathrm{Fe}$ (Fig. 5d). The incomplete contraction may indicate the presence 
a)
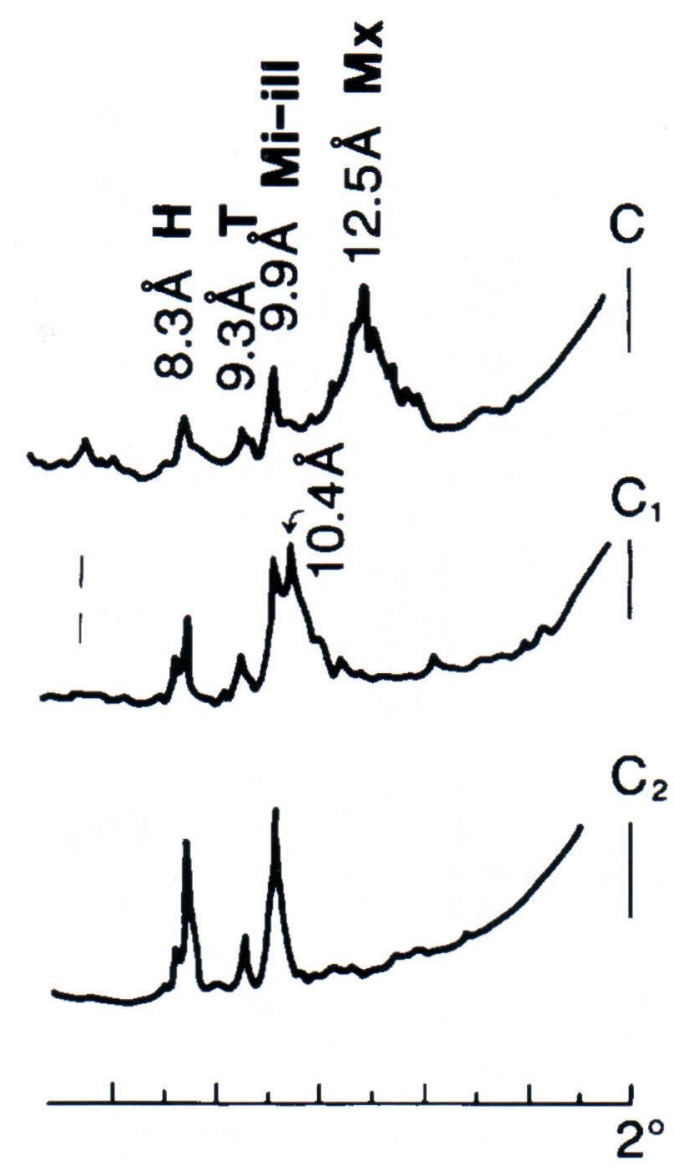

b)
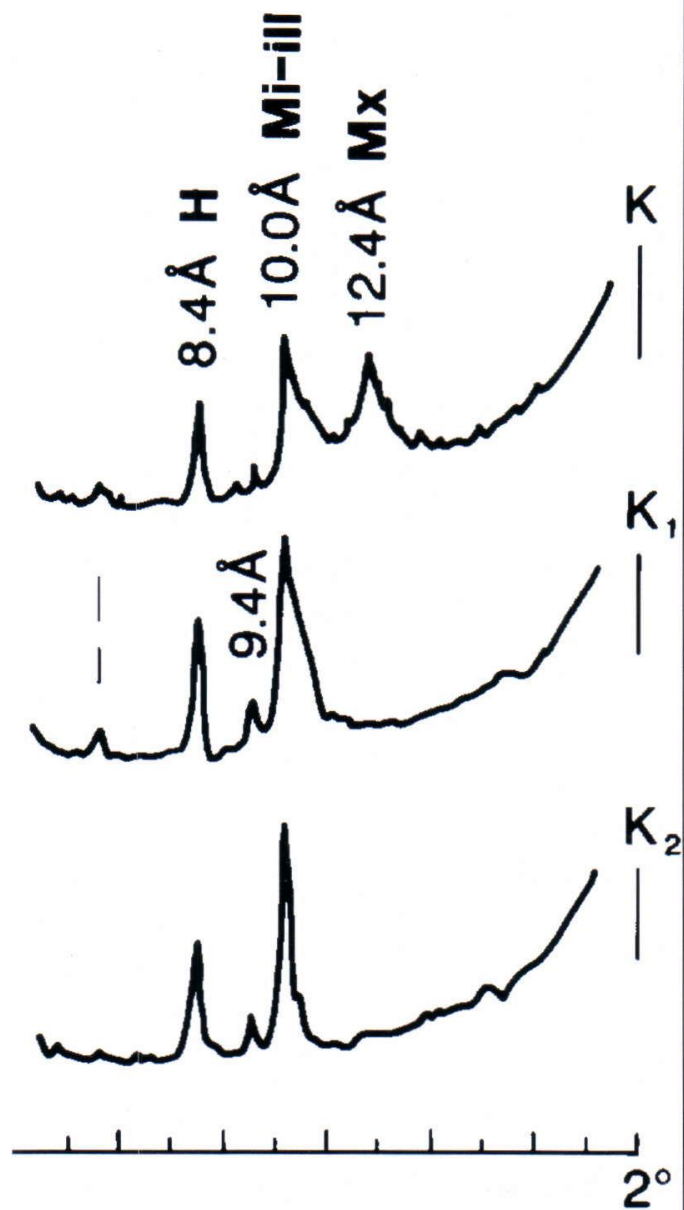

Fig. 3. XRD patterns of the eluvial layer at site No. 3 (background) near Apatity. The grain size of the subsamples was $<40 \mu \mathrm{m}$. Key to the treatments: $C=$ air-dried, $K=K$-saturated, $A=A S_{p H 2}$ extracted, Ox $=$ oxalate extracted, subindex $1=$ heating at $200^{\circ} \mathrm{C}$, subindex $2=$ heating at $550^{\circ} \mathrm{C}$; see also Fig. 2.

of unleached precipitates, which obscure the resolution into an interlayered component and 'true' chloritic component (Carstea et al. 1970). Nevertheless, both mixed-layer clay types, presented in Figs 5 and 6, can be interpreted to have the interstratified structure of vermiculite and chlorite. The highly resistant interlayers of the mixed-layer clay with incomplete contraction at $550^{\circ} \mathrm{C}$ and flat reflections may indicate transformation to the more chloritized structure of the 2:1 layer-silicate (cf. 


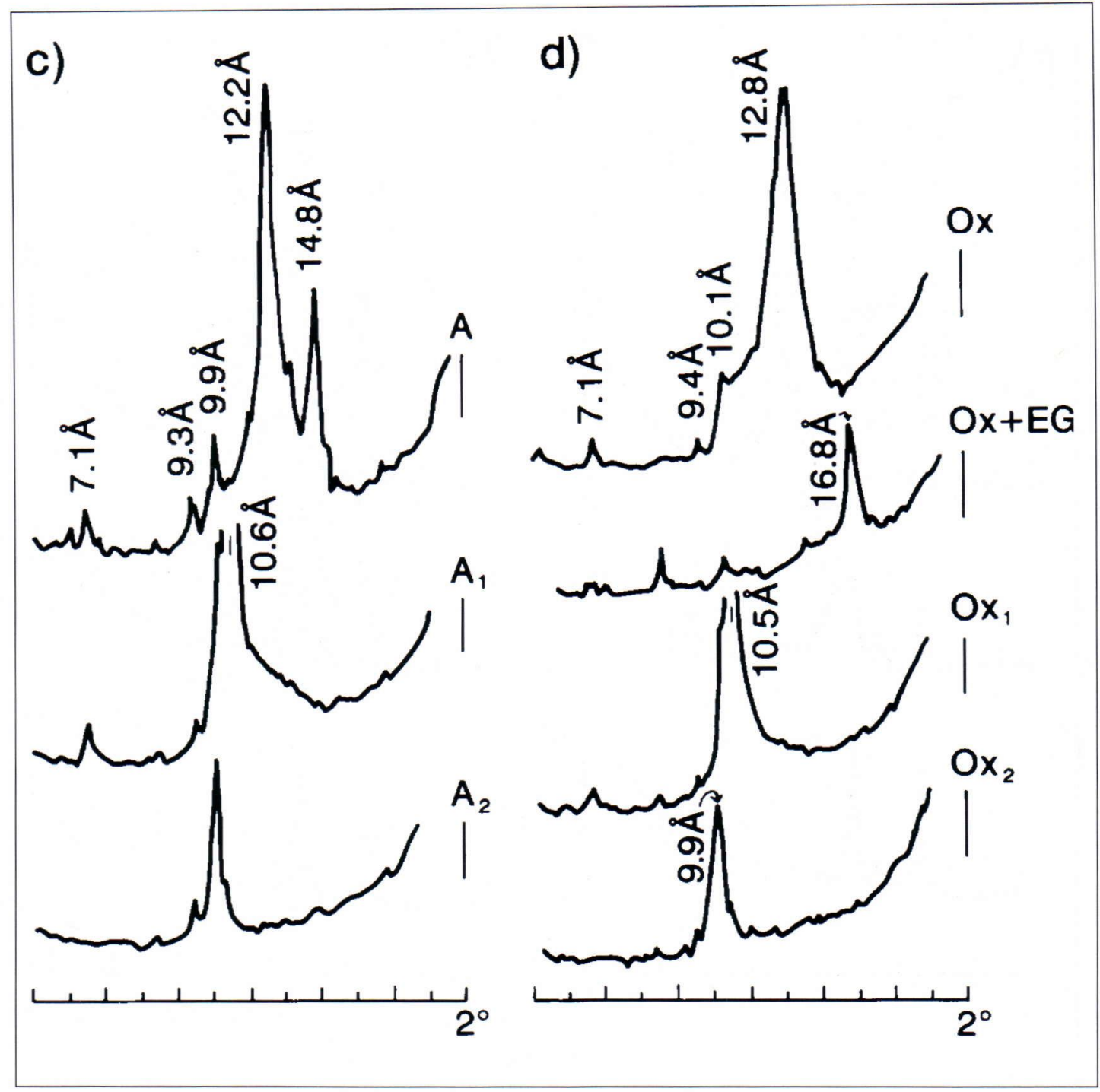

Farmer et al. 1988, Wada et al. 1987). However, the 'more chloritized' mixed-layer clay form was only observed in one of the profiles sampled from the barren soil surface of the totally destroyed forest area. The eluvial layer of the same profile contained chlorite-aluminous montmorillonite.

In addition, most of the samples of both illuviated $(\mathrm{B}, \mathrm{BC})$ layers displayed a weak reflection between $12 \AA$ and $13 \AA$. After the acidic $\mathrm{AS}_{\mathrm{pH} 2.3-2.4}$ and oxalate extractions it shifted closer to the stronger $14 \AA$ A reflection, or eventually became merged with it (Fig. 5). The weak reflection at $24 \AA$ observed for a few samples was attributed to an isolated, regularly interstratified clay form (Fig. 6). Since the peak at $12 \AA$ was unaffected by ethylene glycol or $\mathrm{K}$-saturation, we attribute it to a mica-vermiculite with hydroxy interlayers. The traces were weak, however, and the $12 \AA$ clay was indefinable in most 
Fig. 4. XRD patterns of the eluvial layer from a patch of barren soil at site No. 1 in the totally destroyed forest area, Monchegorsk. The fraction size was $<40$ $\mu m$ in figures $a-c$ and $<10 \mu \mathrm{m}$ in figure $d$. See explanations in Figs. 2 and 3. a)

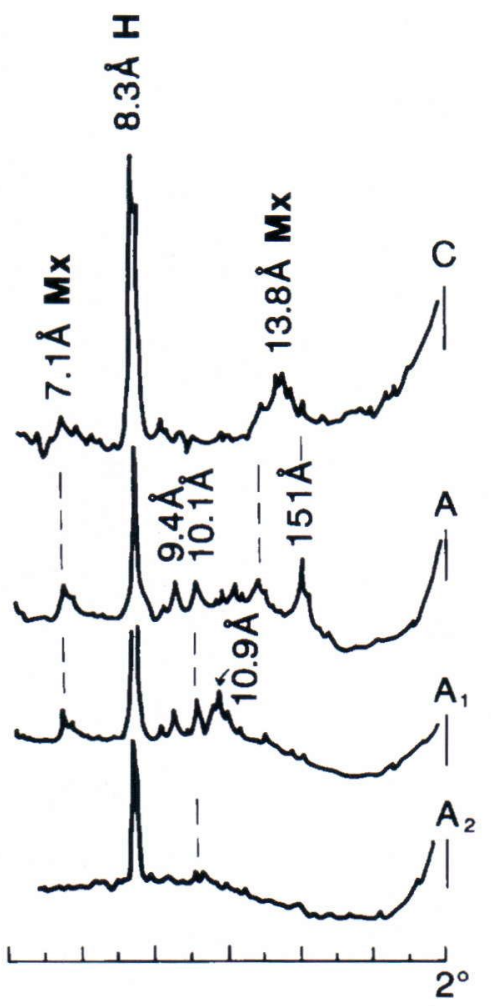

b)

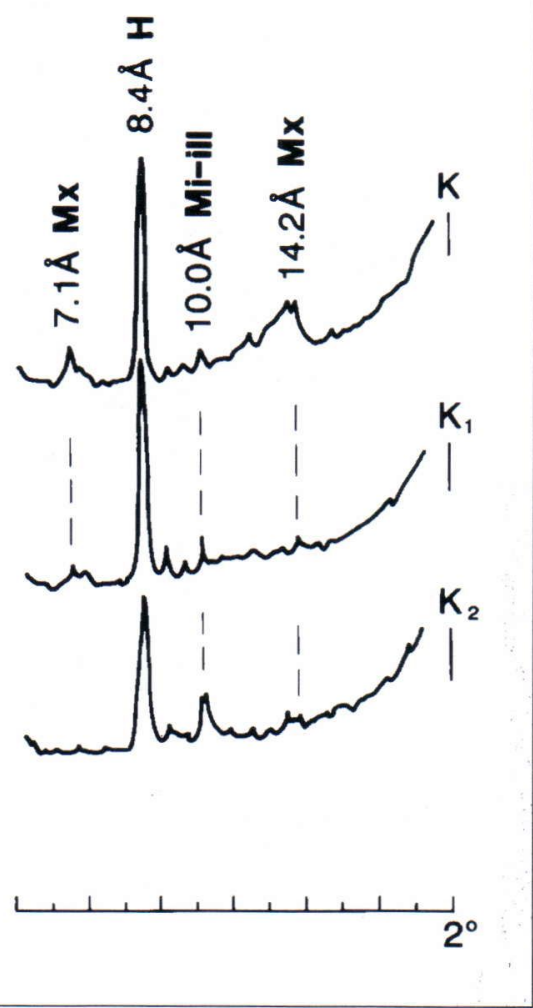

of the samples of the illuviated layers.

\section{Mixed-layer clay minerals in the parent till}

The parent till (C) layers in both the destroyed forest area and the background area were dominated by a non-swelling vermiculite-chlorite. In general, this mixed-layer clay had a lower degree of interlayering than the vermiculite-chlorite in the illuviated layers. However, the abundance of chlorite varied with the sampling site. The mixed-layer clay in till from site No. 1 contained more chlorite and more resistant interlayers of vermiculite than that from site No. 2 . The mixed-layer clay (14 $\AA$ ) from site No. 3 fell somewhere between these. At site No. 4, by contrast, the parent till contained abundant chlorite with a minor amount of the hydroxy interlayered vermiculite.

The abundance of chlorite in the till at site No. 1 may be due to the gabbro bedrock, varying in composition from amphibole-rich to anorthosite gabbros (Gorbunov et al. 1985). According to our field observations (see also Belyaev et al. 1976), at sites Nos 2 and 4 the influence of the mafic bedrock is probably diluted by felsic rocks, and at site No. 3 the influence is minimal.

The mixed-layer clay with the $12 \AA$ spacing was observed at site No. 3. As it had some properties similar to the clay type of the illuviated layers, it is attributed to mica-vermiculite with hydroxy 


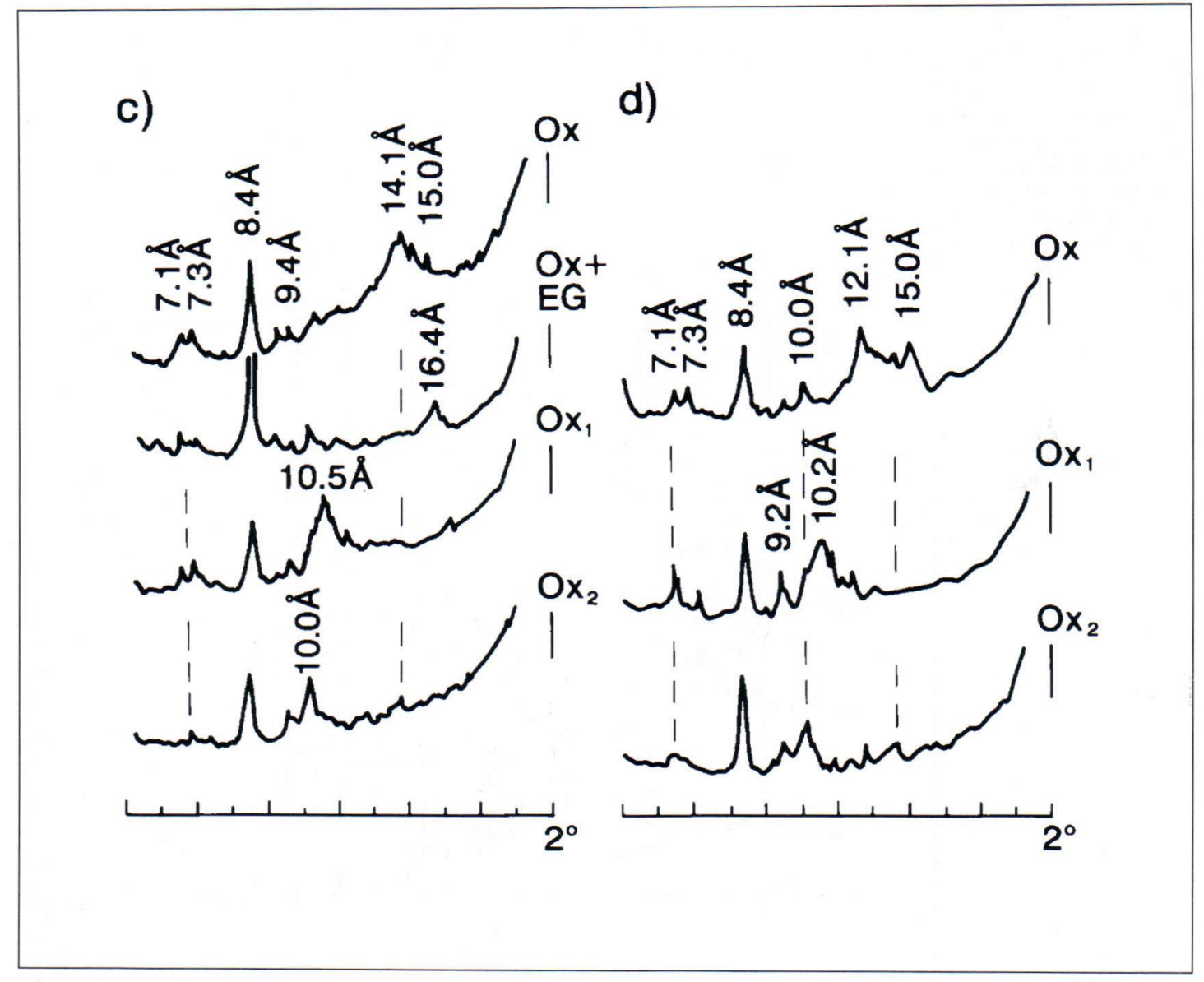

d)

interlayers. The absence of the integral diffraction peak points to a random rather than a regular interstratification.

\section{Weathering reactions within the podzolized} till profiles

Several mineralogical studies from glaciated regions suggest that the most important weathering processes of podzols are the complete or nearly complete decomposition of trioctahedral micas (mainly biotite) and chlorite in the clay fraction of the eluvial layer (Kodama \& Brydon 1968, Kodama 1979, Kapoor 1972, Melkerud 1984, April et al. 1986). The absence of trioctahedral mica and the presence of a minor amount of dioctahedral mica in the interstratified clays of eluvial layer samples indicate that the micas in the top layers of the podzolized tills were vermiculized in the early stages of the weathering sequence. The minor content of hot aqua regia extractable $\mathrm{K}$ also implies the total breakdown of trioctahedral micas in the $<64 \mu \mathrm{m}$ fraction of the eluvial layer. The continued weathering of the eluvial layer has progressively transformed vermiculite to a more swelling smectitic-like layer, as also reported by Brydon et al. (1968), Ross et al. (1982) and Melkerud (1984). This alteration product was observed at all study sites regardless of the geochemical composition of the bedrock and parent tills. We therefore propose 


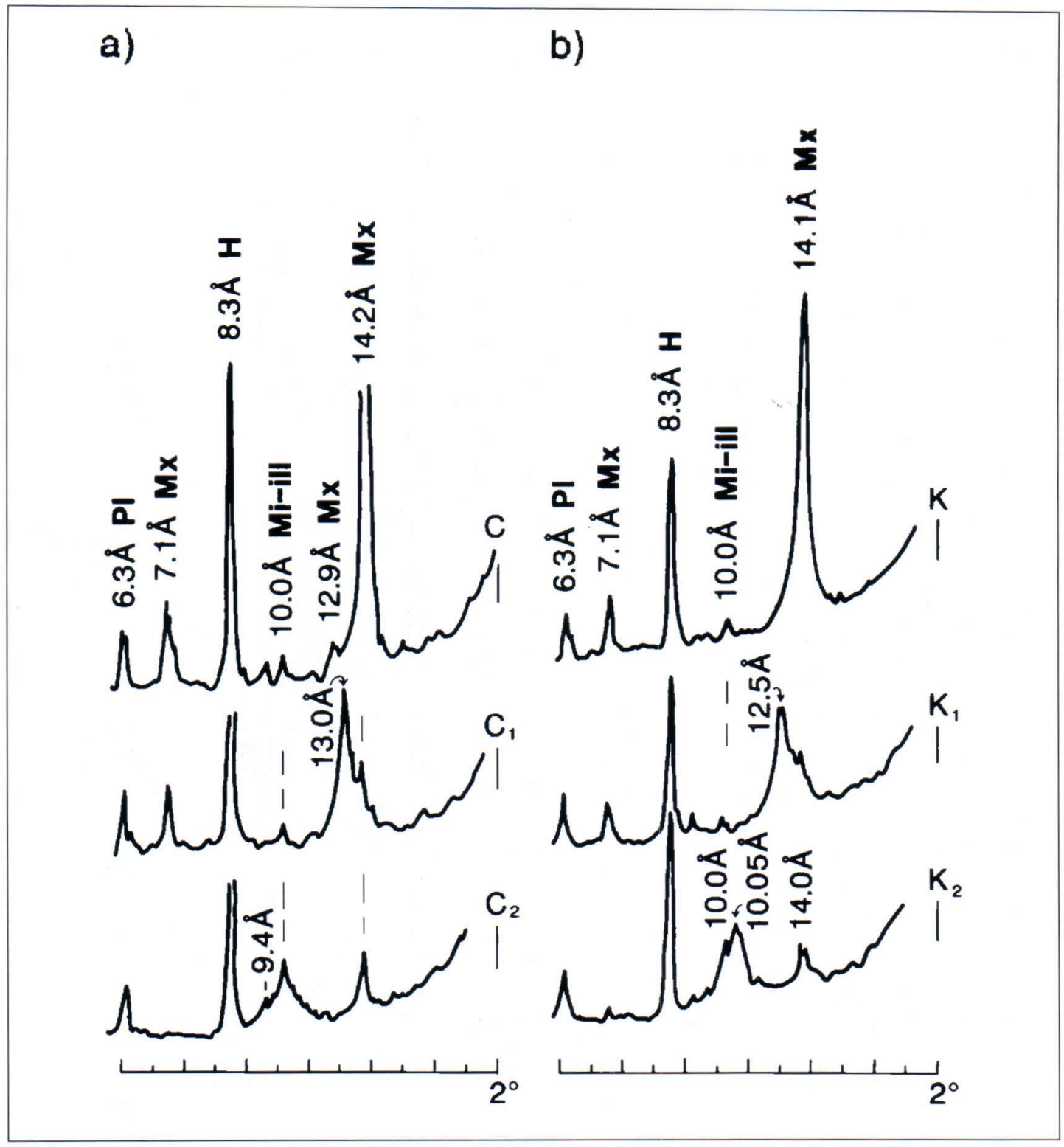

Fig. 5. XRD patterns of the illuvial (B) layer at site No. 3 (background) near Apatity. The grain size of the subsamples was $<40 \mu \mathrm{m}$. The sample was taken from the same profile as the sample of the eluvial layer presented in Fig. 3. See explanations in Figs 2 and 3.

that the smectitic mixed-layer clay mineral is formed during the long-term weathering (natural acidification) of podzolized tills.

The present investigation confirmed the absence of chlorite in the silt+clay fraction $(<64 \mu \mathrm{m}$ or $<40$ $\mu \mathrm{m})$ of most of the eluvial layer samples. As indicated by the peak intensity at $14 \AA$ in samples heated at $550^{\circ} \mathrm{C}$, the abundance of chlorite increased 


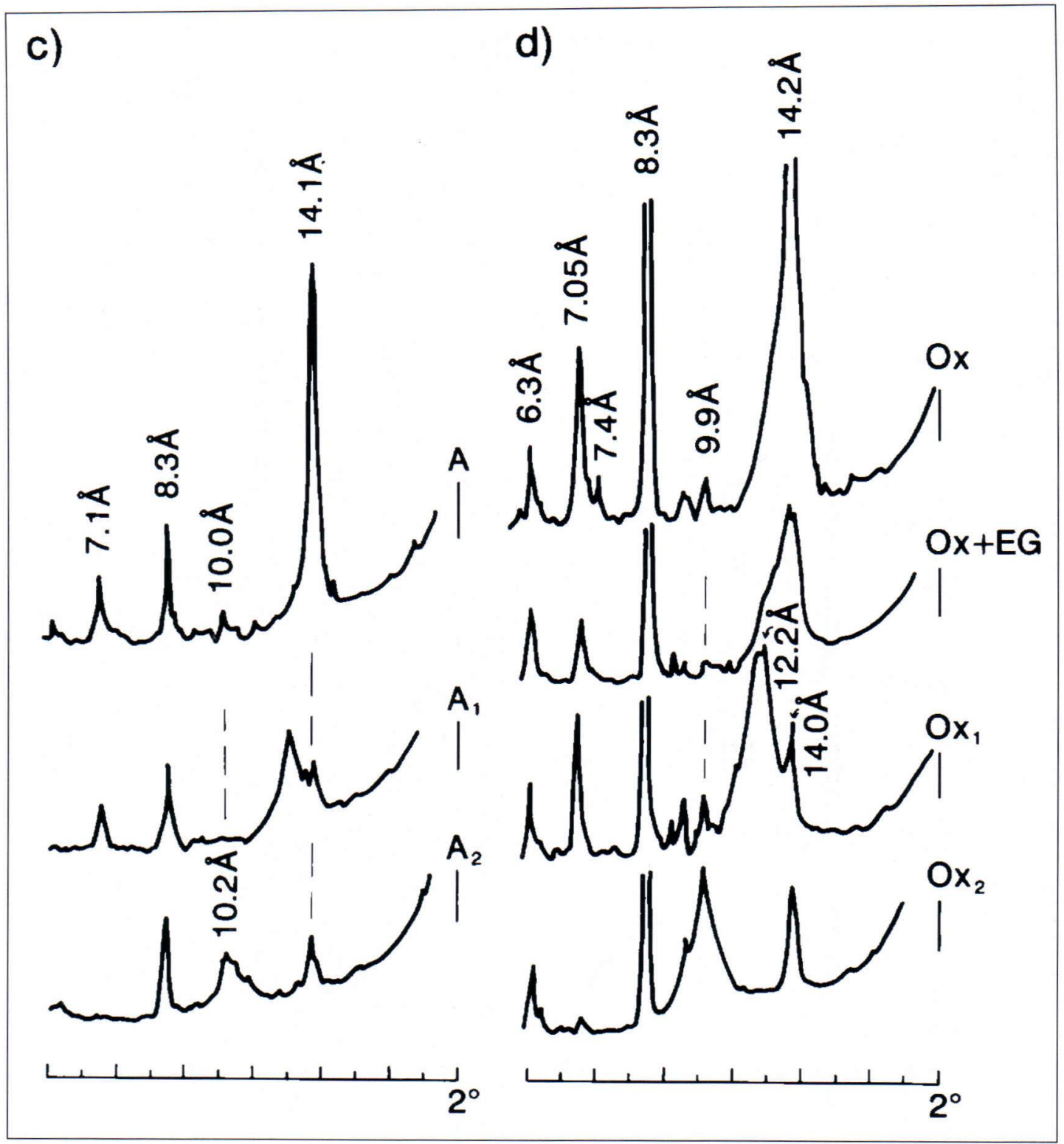

from the illuvial layer downwards to the parent till in all profiles studied. Teveldal et al. (1990) have suggested that the breakdown of chlorite, unlike that of micas, does not result in the neoformation of a stable clay mineral in the eluvial layer. The silica, $\mathrm{Al}$ and Fe released in chlorite weathering are mostly leached out and precipitated in the $\mathrm{B}$ and $\mathrm{BC}$ layers. In illuviated (B, BC) layers, vermiculite was the dominating clay mineral with various interlayering of hydroxy polymers (chloritization), as also reported by Laverdière et al. (1977), Melkerud (1984), and April et al. (1986). Differences in 
a)

)

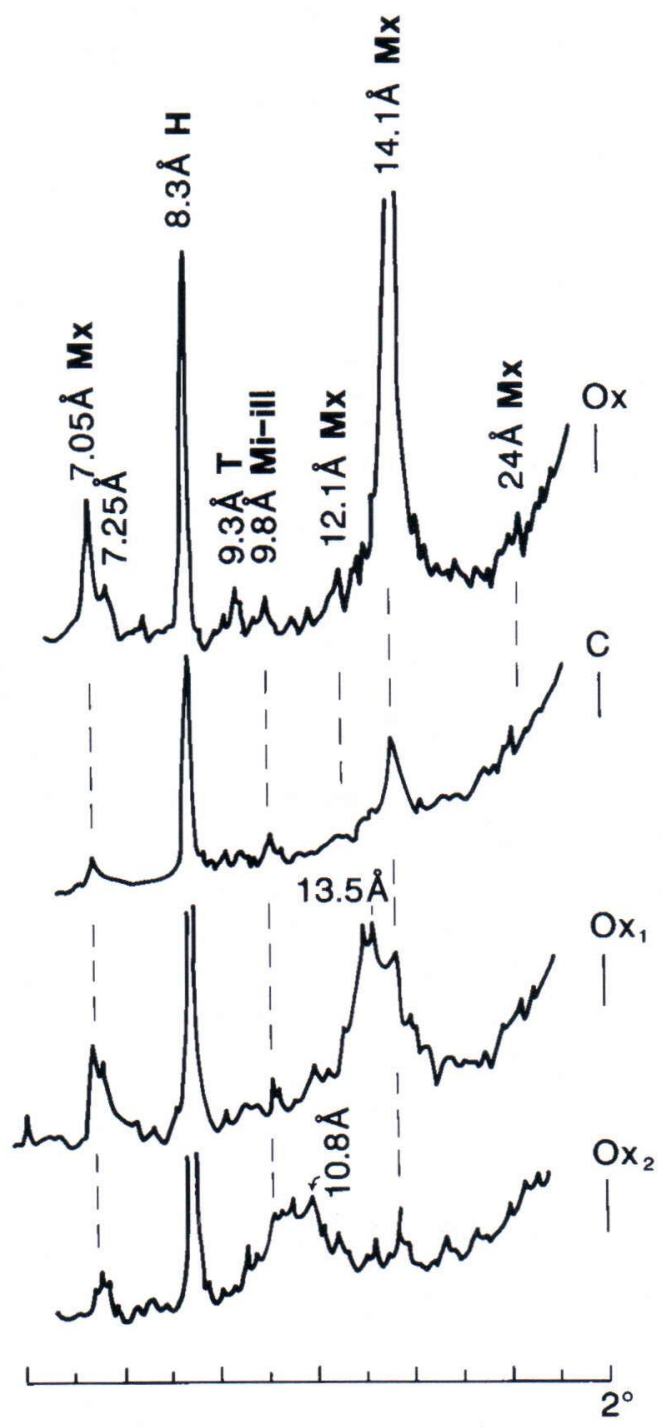

b)

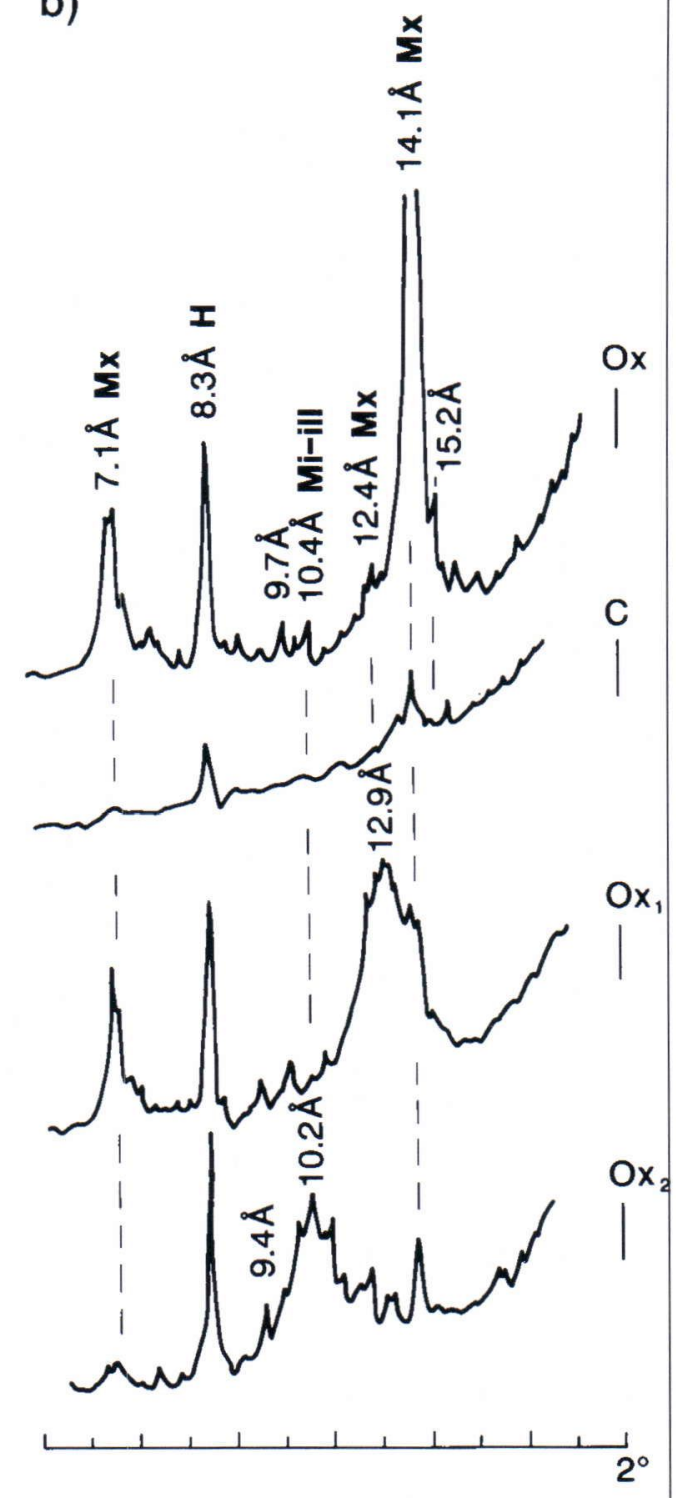

Fig. 6. XRD traces of the air-dried and oxalate-treated samples of the illuviated (B) layer (a), and underlying BC layer (b) at site No. 1 in the totally destroyed forest area, Monchegorsk. The grain size of the subsamples was $<10 \mu \mathrm{m}$. Samples were taken from the same profile as the sample of the eluvial layer presented in Fig. 4 . See explanations in Fig. 3. 
bedrock seemed to control the chlorite in the parent tills, whereas pedogenic and climatic factors of the illuviated layers control the abundance of chloritic residue and the chloritization (hydroxy interlayering) of vermiculite in the mixed-layer clays (Räisänen et al. 1992, see also Ross et al. 1982).

Exceptionally, in a few eluvial layer samples from the totally destroyed forest area a chloritized mixed-layer clay (chlorite-aluminous montmorillonite) occurred side by side with a mica-vermiculite-smectite interstratification. According to diffractograms recorded at $550^{\circ} \mathrm{C}$, the degree of filling of the interlayer space was greater in the chlorite-aluminous montmorillonite than in the mica-vermiculite-smectite (see Figs $3 \mathrm{~d}$ and $4 c-d)$. No clay form with a similar chloritized structure was observed in the eluvial layer samples from the background area.

Both the chloritized interstratification and the mica-vermiculite-smectite gave an expanded spacing at $15 \AA$ after the acidified ammonium nitrate extraction $\left(\mathrm{AS}_{\mathrm{pH} 2.3-2.4}\right)$. The expanding showed that in any strong acidic medium these two mixed-layer clays adsorb free hydroxides into the interlayer sites. However, mica-vermiculitesmectite treated with the $\mathrm{AS}_{\mathrm{pH} 2.3-2.4}$ solution and heated at $550^{\circ} \mathrm{C}$ displayed complete contraction to an intense peak at $10 \AA$, while the chloritized mixed-layer clay treated in the same way exhibited only a slightly stronger $10 \AA$ reflection (cf. Figs 3c and 4a).

Organic acids in the top mineral soil layer, immediately below the organic layer, are widely assumed to prevent the formation of hydroxy-interlayers (chloritization) or to dissolve preexisting hydroxy-interlayers or chlorite (Violante \& Violante 1980, Singer \& Huang 1993). In our case, the eluvial layer (at site No. 1) in which chloritized interstratification was observed lacked an overlying humus layer because of the erosion. The production of organic acids had ceased and the external conditions in the top mineral soil layers had changed drastically. It can be proposed that exposure of the podzolic mineral soil layers promotes the mobilization of Al-hydroxides via percolation of acidic rain water (cf. Räisänen 1989). Lou \& Huang (1990) and Huang (1991) suggested that expandable clay mineral, when present in sufficient amount, can prevent the formation of discrete noncrystalline aluminosilicate from a hydroxy-aluminosilicate solution through the interlayer adsorption mechanism. It could be concluded, therefore, that inputs of Al-hydroxides into interlayer spaces of the vermiculitic component have transformed the mica-vermiculite-smectite to chlorite-aluminous montmorillonite.

Feasibly, an alternative source for the chloritealuminous montmorillonite could be the degradation of pre-existing chlorite component from the coarser fraction than $64 \mu \mathrm{m}$. Arguing against this, hornblende, a possible pool of secondary chlorite, seemed to stay unweathered in the fractions $<40$ $\mu \mathrm{m}$ and $<10 \mu \mathrm{m}$, judging by the sharp reflections at 8.3-8.4 $\AA$ (e.g. Figs. 2 and 4). Moreover, Teveldal et al. (1990) report that chlorite is decomposed almost completely, even in the sand fraction of the eluvial layer, during the Holocene epoch of 9400 years. Podzolized tills in the study area have presumedly formed in this time (Niemelä et al. 1993). Vermiculitization of chlorite, which prefers moderate, non-eluvial weathering conditions, and further alteration of this to a smectitic mixed-layer clay, is likewise excluded (Ross et al. 1982).

Finally, the source of the extra Al-hydroxides may be the intensified weathering of plagioclase as suggested by the decreased concentrations of $\mathrm{Na}$ and $\mathrm{Ca}$ in the eluvial layer and increased concentrations of $\mathrm{Al}$ in both the eluvial and illuviated layers.

\section{CONCLUSIONS}

Trioctahedral mica and chlorite were totally weathered from the silt and clay fraction $(<64 \mu \mathrm{m})$ of the eluvial layer at all study sites in the central 
Kola Peninsula. Only dioctahedral mica occurred in the eluvial layer. The following distribution of mixed-layer clays was observed in most of the podzolized till profiles of the study: an expanding three-component interstratification containing mica, vermiculite and smectite with low levels of interlayering in the eluvial layer, and a non-swelling vermiculite-chlorite with polymerized hydroxy interlayers in the illuviated $(\mathrm{B}, \mathrm{BC})$ layers. The abundance of chlorite and the degree of interlayering of vermiculite in the parent till varied from site to site.

On the whole, characteristics of the mixed-layer clays were similar in most of the podzolic layers of the destroyed forest area (sites Nos 1 and 2) and the background area (sites Nos 3 and 4). The expanding layers of the smectitic-like component were present in the eluvial layer and there was a high degree of interlayering of the vermiculitic component in the illuviated layers at all sites regardless of the geochemical composition of the parent tills and bedrock.

\section{REFERENCES}

April, R. H., Hluchy, M.M. \& Newton, R.M., 1986. The nature of vermiculite in Adirondack soils and till. Clays and Clay Minerals 34, 549-556.

Bain, D.C., Mellor, A. \& Wilson, M.J., 1990. Nature and origin of an aluminous vermiculitic weathering product in acid soils from Upland catchments in Scotland.
Exceptionally, poorly crystalline mixed-layer clay was observed in a few eluvial layers of the totally destroyed forest area. We infer that this chloritized clay (chlorite-aluminous montmorillonite) was recently formed through inputs of Al-hydroxides into interlayer spaces of vermiculite. The source of the extra Al-hydroxides was the weathering of plagioclase, probably intensified in barren places by strongly acidic rain water.

ACKNOWLEDGEMENTS: We thank Drs G. Kasulina, $N$. Lukina and V. Nikonov from the Institute of Ecological Problems of the Kola Scientific Centre in Apatity for assistance with field sampling and their helpful discussions. The authors are grateful to Prof. Heikki Papunen, Department of Geology, University of Turku for his interest and constructive criticism throughout the various stages of the study.

Clay Minerals. 25, 467-475.

Barnhisel, R.I., 1977. Chlorites and hydroxy interlayered vermiculite and smectite. In: J.B. Dixon \& S.B. Weed, Minerals in Soil Environments, Soil Science Society of America, Madison, Wisconsin, 331-356.

Barnhisel, R.I. \& Bertsch, P.M., 1989. Chlorites and hydroxy interlayered vermiculite and smectite. In: J.B. Dixon \& S.B. Weed, Minerals in Soil 
Environments Second Edition, Soil Science Society of America, Madison, Wisconsin, 729-787.

Belyaev, O.A., Zagorodny, V.G., Petrov, V.P. \& Volotsin, E.M., 1976. Shema fatsii regionalogo metamorfizma. Kolskogo polyostrov, 1:1 000000.

Brydon, J.E., Kodoma, H. \& Ross, G.J., 1968. Mineralogy and weathering of the clays in orthic podzols and other podzolic soils in Canada. Transactions of the 9th International Congress of Soil Science III, 41-51.

Carstea, D.D., Harward, M.E. \& Knox, E.G., 1970. Comparison of iron and aluminium hydroxy interlayers in montmorillonite and vermiculite. Soil Science Society of America Proceedings 34, 522-526.

Dixon, J. \& Weed, S.B., 1977. Minerals in soil environments. First edition. Soil Society of America, Madison, Wisconsin.

Dixon, J. \& Weed, S.B., 1989. Minerals in soil environments. Second Edition. Soil Society of America, Madison, Wisconsin.

Farmer, V.C., Smith, B.F.L., Wilson,M.J., Loveland, P.J. \& Payton, R.W., 1988. Readily-extractable hydroxyaluminium interlayers in clay- and silt-sized vermiculite. Clay Minerals 23, 271-277.

Gorbunov, G.I., Yakovlev, YU.N., Goncharov, YO.V., Gorelov, V.A. \& Tel'nov, V.A., 1985. The nickel areas of the Kola Peninsula. Geological Survey of Finland Bulletin 333, 41-109.

Honkanen, H., 1992. Ympäristötutkimusta Kuolassa. Ympäristö ja Terveys 1, 54-69.

Huang, P.M., 1991. Ionic factors affecting the formation of short-range ordered aluminosilicates. Soil Science Society of America Journal 55, 1172-1180.

Jackson, M.L., 1963. Interlayering of expansible layer silicates in soils by chemical weathering. Clays and Clay Minerals 11, 29-46.

Jevtjugina, Z., 1991. The atmospheric pollution load on forest ecosystems in the central part of the Kola Peninsula.The Finnish Forest Research Institute, Research Papers 373, 132-141.

Kapoor, B.S., 1972. Weathering of micaceous clays in some norwegian podzols. Clay Minerals 9, 383-394.

Kasulina, G., 1991. Spatial variation in podzol development in a spruce ecosystem in the Kola Peninsula. The Finnish Forest Research Institute, Research Papers 373, 142-152.

Kodama, H., 1979. Clay minerals in Canadian soils: their origin, distribution and alteration. Canadian Journal of Soil Science 59, 37-58.

Kodama, H. \& Brydon, J.E., 1968. A study of clay minerals in podzol soils in New Brunswick, eastern Canada. Clay Minerals 7, 295-309.

Kodama, H. \& Schnitzer, M., 1973. Dissolution of chlorite minerals by fulvic acid. Canadian Journal of
Soil Science 53, 240-243.

Kontio, M., Pulkkinen, E. \& Räisänen, M. L., 1992. Lapin maaperän ravinteisuus ja happamoitumisherkkyys geologian ja geokemian kannalta. Abstract: Nutrients and sensitivity to the acidification of mineral soils of Lapland with emphasis on geology and geochemistry. The Finnish Forest Research Institute, Research Papers 413, 61-72.

Kryuskov, V.V., 1991. Heavy metal accumulation in spruce needles and changes of northern taiga ecosystems. Geological Survey of Finland, Special Paper 9, 177-184.

Kryuskov, V.V.\& Makarova, T.D., 1989. Aerotehnogennoje vozdejstvije na ekosistemy Kolskogo Severa. Report of Kola Scientific Centre, Apatity.

Laverdière, M.R., Weaver, R.M. \& D'Avignon, A., 1977. Characteristics of the mineral constituents of some albic and spodic horizons as related to their charge properties. Canadian Journal of Soil Science 57, 349-359.

Lindén, A., 1975. Till petrographical studies in an Archaean bedrock area in southern central Sweden. Striae $1,57 \mathrm{p}$.

Lou, G. \& Huang, P.M., 1988. Hydroxy-aluminosilicate interlayers in montmorillonite: implications for acidic environments. Nature 335, 625-627.

Lou, G. \& Huang, P.M., 1990. Effect of montmorillonite on the formation of noncrystalline aluminosilicates. Transactions of the 14th International Congress of Soil Science 7, 402-403.

MacEwan, D.M.C. \& Wilson, M.J., 1980. Interlayer and intercalation complexes of clay minerals. In: G. M. Brindley \& G. Brown, Crystal structures of clay minerals and their X-ray identification, Mineralogical Society Monograph No. 5, London, 197-248.

McKeague, J.A. \& Day, J.H., 1966. Dithionite and oxalate extractable $\mathrm{Fe}$ and $\mathrm{Al}$ as aids in differentiating various classes of soils. Canadian Journal of Soil Science 46, 13-22.

Melkerud, P-A., 1984. Distribution of clay minerals in soil profiles - A tool in chronostratigraphical and lithostratigraphical investigation of till. Striae 20, 31-37.

Olson, C.G., 1988. Clay-mineral contribution to the weathering mechanisms in two contrasting watersheds. Journal of Soil Science 39, 457-467.

Olsson, M., 1992. Soils in northern Fennoscandia and Kola Peninsula from an environmental point of view - monitoring and present state. In: Tikkanen, E., Varmola, M. \& Katermaa, T., Symposium on the State of the Environment and Environmental Monitoring in Northern Fennoscandia and the Kola Peninsula, Arctic Centre Publications 4, Rovaniemi, 
51-64.

Perttunen, M., 1977. The lithologic relation between till and bedrock in the region of Hämeenlinna, southern Finland. Bulletin of the Geological Survey of Finland 291, 68 p.

Rich, C.I., 1968. Hydroxy interlayers in expansible layer silicates. Clays and Clay Minerals 16, 15-30.

Ross, G.J., Wang, C., Ozkan, A.I. \& Rees, H.W., 1982. Weathering of chlorite and mica in a New Brunswick podzol developed on till derived from chlorite-mica schist. Geoderma 27, 255-267.

Räisänen, M. L., 1989. Mineraalimaan happamoituminen eräillä koealoilla teollisuuden lähiympäristössä ja tausta-alueilla Suomessa. Summary: The acidification of podzolized mineral soils in background areas and near industrial areas in Finland. Geological Survey of Finland, Report of Investigation 91, 74 p.

Räisänen, M.L., Tenhola, M. \& Mäkinen, J., 1992. Relationship between mineralogy and the physico-chemical properties of till in central Finland. Bulletin of the Geolological Society of Finland 64, Part I, 35-58.

Soveri, U. \& Hyyppä, J.M.I., 1966. On the mineralogy of fine fraction of some Finnish glacial tills. The State Inst. for Technical Research, Finland, Publication 113, $31 \mathrm{p}$.
Teveldal, S., Jörgensen, P. \& Stuanes, A.O., 1990. Longterm weathering of silicates in a sandy soil at Nordmoen, southern Norway. Clay Minerals 25, 447-465.

Thorez, J., 1975. Phyllosilicates and clay minerals. A laboratory handbook for X-ray diffraction analysis. G. Lelotte, Dison, Belgique.

Tuovinen, J.-P., Kangas, L. \& Nordlund, G., 1990.

Model calculations of sulphur and nitrogen deposition in Finland. In: P. Kauppi, P. Anttila \& K. Kenttämies, Acidification in Finland. Springer-Verlag, Berlin Heidelberg, 167-197.

Wada, K., Kakuto, Y. \& Fukuhara, K., 1987.

"Chloritized" vermiculite and smectite in some Inceptisols and spodosols. Soil Science and Plant Nutrient 33, 317-326.

Weaver, C.E., 1989. Clays, muds, and shales. Developments in Sedimentology 44, pp. 1-188. Elsevier, Amsterdam.

Wilson, M.J., 1987. A handbook of determinative methods in clay mineralogy. Blackie \& Son Ltd, New York.

Violante, A. \& Violante, P., 1980. Influence of $\mathrm{pH}$ concentration, and chelating power of organic anions on the synthesis of aluminium hydroxides and oxyhydroxides. Clays and Clay Minerals 28, 425-434. 